DOI 10.15290/oolscprepi.2018.52

\title{
OPTIMIZATION OF PUBLIC REVENUES AND EXPENDITURE ${ }^{1}$
}

\author{
MARIE KARFÍKOVÁ2
}

\begin{abstract}
This article concerns public income and expenditure optimization with a focus on legal regulation contained in tax laws. The considered area is particularly legal optimization of duties that are analyzed from a state's point of view, on the one hand, and from tax payer's point of view, on the other hand. The state's main concern is tax evasion which is an unwanted form of optimization from a state's point of view. On the contrary, practice, and articles published by tax advisors, auditors and attorneysat-law show tax optimization as reaching the smallest possible tax burden for the tax payer. Tax evasion is undoubtedly socially harmful and it is necessary to fight it not only by a quality legislature drafting flawless (i.e. simple and well-arranged without a possibility of double interpretation) legal norms but even by criminal procedure. Even though a question connected to an effectiveness of tax system (e.g. an impact of taxes on taxpayers) has been relatively explored - and no one is going to be surprised that if taxes from different social, political, moral or economic reasons should be used for steadier national product redistribution, it is necessary to know impact of such taxes up front. Although the effects of taxes on individual taxpayers have an overall impact on the development of the economy, these aspects are often not given an appropriate attention in terms of tax system development and tax policy as a whole.
\end{abstract}

\section{Keywords}

Public law; tax law; tax laws; optimization of public revenues; optimization of tax expenses

\section{JEL Classification: H20, H60, K15}

1 This paper has been elaborated within the programme "PROGRES Q02 - Publicization of Law in the European and International Context" which is realized in 2018 at the Faculty of Law of the Charles University. Professor of Financial Law and Financial Science, Department of Financial Law and Financial Science, Faculty of Law, Charles University, Czech Republic. The Author specializes in tax law and insurance law. She is the author or co-author of more than 10 books and 80 reviewed articles. She is a member of Information and Organization Centre for the Research on the Public Finances and Tax Law in the Countries of Central and Eastern Europe. Orcid.org/0000-0002-5655-7858. Contact email: karfikov@prf.cuni.cz. 


\section{Introduction}

In common and professional life, we often encounter situations where a number of concepts are defined in general terms, some are defined only for the purpose of a particular law, and some are even used without being defined by law at all. For example, the term immovable property is defined in Sec. 498/1 of Civil Code (hereinafter referred to as the "Civil Code") when at the same time the relevant provision also negatively defines the term of movable property. Just as it was the case in the past, the Civil Code now deals with a definition of movable and immovable property by defining only immovable property, whereby all other things that are not immovable, whether of a corporeal or incorporeal nature, are movable. Every property (thing) is either immovable if it fulfills the legal definition contained in the first paragraph of Sec. 498 or the features contained in the definition are not fulfilled and then it is always movable property. The definition of the immovable property is therefore decisive for defining both categories of things; either is a specific thing an immovable property under this definition, or the features contained in the relevant provision are not met, which means the thing is movable. On the other hand, some concepts are used by law without being defined, such as the term tax. This term has no general definition, only certain tax laws define the subject matter of a tax and thus distinguish each other.

As I have mentioned the concept of tax (the same applies to a fee), then it is interesting for the purposes of interpretation to point out the provision 1811/2/c of the Civil Code which stipulates the following obligation: "If the dealings of the parties aim at concluding a contract and these facts are not evident from the context, the entrepreneur shall, sufficiently in advance before the conclusion of the contract or before the consumer makes a binding offer, provide the consumer with: (...) c) the price of the goods or service, or, where applicable, the method of its calculation including all taxes and fees."

Legal literature commenting on this provision states that information about the price, taxes and fees are required (Pelikánová, 2017). It implies incorporation of the consumer protection included in the Council Directive 93/13/EEC on unfair terms in consumer contracts and within the meaning of Art. 5/1 of Directive 2011/83/EU on consumer rights. The Civil Code imposes the same obligation which is included in the second mentioned directive that states that before the consumer is bound by a contract other than a distance or an off-premises contract, or any corresponding offer, the trader shall provide the consumer with the information about "the total price of the goods or services inclusive of taxes, or where the nature of the goods or services is such that the price cannot reasonably be calculated in advance, the manner in which the price is to be calculated, as well as, where applicable, 
all additional freight, delivery or postal charges or, where those charges cannot reasonably be calculated in advance, the fact that such additional charges may be payable". The meaning of the Czech term "fees" must be interpreted in accordance with the directive as freight, delivery or postage "charges". The Czech provision appears to be stricter in a certain way as it requires the information on "all" taxes and fees, although according the directive it would only be sufficient to provide the consumer with information in a clear and comprehensible manner that additional charges may be payable. Based on a purely grammatical interpretation of this provision, it will be interesting to see how the case law deals with application of this obligation as there is no legal definition of taxes and fees (charges). In particular, it may appear problematic to define the term of a fee which has for the purposes of financial law a different meaning than the one discussed and contained in the above private law provisions.

\section{Optimization}

Somewhat problematic in terms of interpretation might be the concepts used in theory and practice, which, however, are not defined but even explained in the applicable laws. For example, the internet encyclopaedia defines the concept of optimization as follows: "In computer science, program optimization or software optimization is the process of modifying a software system to make some aspect of it work more efficiently or use fewer resources. In general, a computer program may be optimized so that it executes more rapidly, or is capable of operating with less memory storage or other resources, or draw less power. Although the word "optimization" shares the same root as "optimal", it is rare for the process of optimization to produce a truly optimal system. The optimized system will typically only be optimal in one application or for one audience" (www.cs.wikipedia.org). In legislation, the notion of optimization is used in a number of laws without any explanation, for example "optimization of methods for reuse" (Act on Waste), "optimization of water regime" (Act on the Protection of Agricultural Land Fund). The term "optimization" is used in no tax law.

The term "optimization" is on the other hand frequently used in explanatory memoranda to tax laws and also in various specialized articles. For example, in June 2016 has been adopted the Council Directive (EU) 2016/1164 laying down rules against tax avoidance practices that directly affect the functioning of the internal market and which sets common rules for corporate taxation in the European Union. This directive is based on the BEEC (Base Erosion and Profit Shifting) project developed within the OECD and must be implemented by the Czech Republic in its law by 31 December 2018. It primarily affects the tax optimization used by 
companies on the internal market, i.e. among the countries of the European Union. But it also contains rules that have the impact on tax accounting in corporate structures operating only on the domestic market, in particular, it will affect the use of debt instruments and external financing, such as bonds, finance lease payments, but also profits to parent companies or other transactions between members of the group. A number of exceptions might exist from the rules set out in the directive and the directive can also be somewhat mitigated, depending on how precisely the Czech legislator will face this area. At present (30 April 2017) a public consultation on how this directive will be reflected in the Income Tax Act is being held. It is based on a minimum level of protection, so the Member States must use at least the regime set out in the directive, but may opt for a stricter option beyond the directive (as can be seen below in the example of limiting the tax deductibility). In my view, the effects of the new legislation will have to be anticipated and slowly adapted to within corporate structures.

Further, for example, the explanatory memorandum to Act no. 170/2016, on the amendment of certain laws in the field of taxes, states the following: "The proposed legislation is related to efforts on avoiding circumvention of the law and the undesired tax optimization". The explanatory memorandum to Act no. 243/2016, amending certain laws in connection with the adoption of the Customs Act, states: "This step will lead to partial optimization of the activities". Explanatory Memorandum to Act no. 254/2016, amending Statutory Measure of the Senate no. 340/2013, on Tax on the Acquisition of Immovable Property, contains the following: "Further, the aim is to make the necessary clarifications of the current legislation and to eliminate ambiguities, including reducing the potential for undesired tax optimization in this area".

\section{Two Views of Optimization of Public Revenues and Expenditure}

In the light of the above, I would like to begin by pointing out that there are two views on optimization of public spending (expenditure) and public revenues. From the point of view of the state, the aim if focused on preventing circumvention of tax laws and the undesirable optimization. On the other hand, practical life and articles of tax advisers, auditors and lawyers consider optimization in the light of the lowest tax liability.

When talking about amendments to the tax system in the Czech Republic, it has become a tradition that any political representation presents its views on optimizing public revenues and public spending through changes in tax rates. As the larger part of the population is practically not much familiar with the concept and construction of the relevant taxes that are imposed and collected on the territory of the state, it is 
only playing with numbers which easier to understand, and in terms of interest even more acceptable.

Given the fact that the majority population is employed, it is not that much concerned whether small or medium-sized Czech entrepreneurs can still create any values and actually carry out their business despite the challenging and demanding tax administration or whether they are only becoming a new administrative centre that assumes the fulfilment of certain obligations instead of the Czech state without being compensated. This is also because the tax rate is crucial for employees whose salary is the only source of income. Although the tax rate is an interesting measure, it is not the decisive one. Rather, it draws attention from the nature of the problem, which is often the ineffective tax system. It is certainly no secret that for making an overall assessment of the effectiveness of a tax system, it is appropriate to measure the tax rate together with the tax-deductible expenses, however, in the Czech Republic, this tool has not become significant so far. This is also the case because taxes and tax system as such are in most cases subject to social engineering, as the legislator tries to address through tax measures problems falling into the sphere of social law.

To understand the issue of optimizing revenues and expenses, the basic concept needs to be clarified at least very briefly. The key will be to clarify the notion of tax optimization which becomes at a certain moment from the point of view of a public budget a tax evasion. Although there are many definitions, I prefer to consider tax evasion as a criminal act that is to say a behavior considered a criminal offense under criminal law. On the contrary, the European Commission has somewhat redundantly distinguished between the concepts of "tax fraud" ("a form of deliberate evasion of tax which is generally punishable under criminal law; the term includes situations in which deliberately false statements are submitted or fake documents are produced"), "tax evasion" ("generally comprises illegal arrangements where tax liability is hidden or ignored, i.e. the taxpayer pays less tax than he/she is supposed to pay under the law by hiding income or information from the tax authorities") and "tax avoidance" ("defined as acting within the law, sometimes at the edge of legality, to minimise or eliminate tax that would otherwise be legally owed, it often involves exploiting the strict letter of the law, loopholes and mismatches to obtain a tax advantage that was not originally intended by the legislation") (European Commission, 2017). The business environment acknowledges the concept of tax optimization as an activity actually reducing the tax liability within the limits of the law.

As mentioned above, the Ministry of Finance repeatedly argues in its explanatory memoranda that it is proposing amendments to tax laws with the vision of eliminating or limiting unwanted tax optimization. On the other hand, tax 
optimization services leading to the reduction of tax liability are legally offered to taxpayers. The theory of financial law then deals permanently with what leads taxpayers to tax optimization: is it low tax morale, ignorance of legal regulation caused by the complexity of tax legislation? If it is for any of the above reasons, it is sure that taxpayers are trying to get a certain benefit. If there is no violation of law, there is no tax evasion. It is a simple, entirely legal, tax optimization (tax minimization), for which, of course, the taxpayer cannot be penalized.

\section{Optimization of Revenues and Expenses in the Case Law of the Constitutional Court}

The issue of public incomes and spending in tax matters is not so often subject to the Supreme Administrative Court's decisions and even less subject of the Constitutional Court's decisions. One of the interesting rulings of the Constitutional Court is the judgment of the Constitutional Court of 21 April 2009, which was published under no. 181/2009. The judgment was based on a motion of the Supreme Administrative Court (hereinafter referred to as the "SAC") aiming to declare the unconstitutionality of the Secs. 8, 9, 10 and 15 of Act no. 357/1992, on Inheritance tax, Gift Tax and Real Estate Transfer Tax, in the wording before the amendment made by Act no. 420/2003. The question that the Constitutional Court could not avoid is whether the Constitutional Court is actually responsible for assessing the real estate transfer tax from the point of view of the functions of taxes discussed by the economic literature to which the SAC refers in its motion to the Constitutional Court. The SAC's motion suggests that the Constitutional Court should assess the unconstitutionality of taxes in terms of the three basic functions of taxation and the tax system, namely the allocation, distribution and stabilization functions (Musgrave, 1994: 6; Kubátová, Vítek, 1997: 12; Kubátová, 2003: 19 or Peková, 2005: 323).

According to the opinion of the Constitutional Court, any reasoning on taxes in the light of the above criteria falls within the competence of a democratically elected body. If the Constitutional Court approached these considerations, it would enter the field of politics and diverse policies of which rationality cannot be sufficiently assessed from the point of view of constitutionality. The Constitutional Court also does not, as a general rule, examine the effectiveness of taxes, subject to cases where the ineffectiveness of a certain tax would create a clear inequality in the tax burden of the individual citizens. The task of the Constitutional Court is only to examine whether the concerned tax measures interfere with the constitutionally guaranteed property substrate of the owner, i.e. if they can be regarded as arbitrary or unjustifiable opposing the principle of equality. In the Constitutional Court's 
view, it should also be borne in mind that all taxes form one system (see paragraphs 48 and 51 of the judgment). As a result, if the Constitutional Court wanted to address the issue of the legitimacy and rationality of the real estate transfer tax, it would also have to deal with the links between the real estate transfer tax and other taxes. Should the Constitutional Court decide to say whether the transfer tax is an appropriate and necessary element of the tax system, it would enter Authoritatively but without a constitutional justification into a debate, in which the professional economic and legal community itself is not uniform as regards the proposals de lege ferenda. For example, an academic publication on tax policy perspectives considers the change of the budgetary allocation of the real estate transfer tax to be the optimal solution, i.e. the Author prefers to maintain this tax in a modified version as opposed to maintain the current state or its complete abolition (Kubátová, Vybíhal et al.: 2004: 152).

If there is no consensus among the relevant experts, it is not the role of the Constitutional Court to speculate on the right answers. The Constitutional Court is aware of the importance of deciding on the tax system in the context of rival political parties, i.e. in the context of wishes and preferences of members of the political community in relation to the degree of the social status of state policies that find a reflection in election results. It is, therefore, necessary to leave these questions to the political majority that was formed by the elections. Engliš already noticed that "the struggle for political power in the state is a struggle to manage the ideal the state is reaching to, a struggle to manage public welfare. To the same extent as the expenditure structure and the incomes, structure are related, the political struggle is also a struggle for a system of public revenues, especially the tax system" (Engliš, 1929: 101). The Constitutional Court does not intend to enter this political competition and is prepared to intervene only if it finds the unconstitutionality of the tax laws in the above-mentioned scope.

The US Supreme Court decided to abolish tax laws only when the classification of tax subjects and the subject of taxation appeared to be arbitrary, which has occurred only in a limited number of cases. In other words, no legislation may arbitrarily establish discrimination. Comparative studies (Ordower) show that the German Federal Constitutional Court acts far more actively in tax cases and has found many times tax laws being in conflict with constitutional principles, which is quite exceptional in the United States. The reason for such difference is probably to be associated with a different interpretation of fundamental rights in the US and Europe. While in the US, fundamental rights are interpreted only as negative rights (the state is obliged to respect fundamental rights), it is a European standard to interpret fundamental rights as well as positive rights (the state has a duty to protect fundamental rights). The above mentioned is confirmed by the fact that the German 
Federal Constitutional Court found the so-called "nuclear fuel tax" to be illegal. As a result of this decision, energy companies required the return of some EUR 6.3 billion, which they have paid to the German state in recent years.

The Constitutional Court stated in its reasoning that it did not intend to review the consistency of tax policy with other policies, such as housing policy, as proposed by the SAC, because it would find itself on the thin ice of not always conclusive economic analyses of which the results are to be assessed and political consequences deduced only by a democratically elected body which also has to consider whether a tax regulation is appropriate and necessary from this point of view. In its motion, the SAC also stated that the cost of a real estate increases by the amount of the tax, but statistics suggest that there is no such direct relationship between these two variables. Some Authors are even more sceptical about the relationship between real estate transfer tax and restrictions on the housing market, population mobility and other negative social consequences: "It is also not certain that the abolition of this tax must have an impact on housing policy and that would significantly increase population mobility or indirectly reduce unemployment" (Radvan, 2007: 353). Because there are no accurate economic analyses available and the SAC has not submitted any within its motion, the SAC bases its conclusions only on what is to be "apparent from the nature of the case" despite that any statement in the domain of social sciences should be based on a complex of multifactorial explanations. The Constitutional Court did not intend to make an Authoritative decision on the relationship between these and perhaps even other variables. In addition, from the analyses available to the Constitutional Court, it does not imply that the real estate transfer tax would be the main brake on the development of the relevant policies and that its influence on labour mobility, entrepreneurship or the deterioration of the social situation would be somewhat critical (see par. 21). The Constitutional Court shall not substitute the opinion of a democratically elected legislator by its own opinion on the appropriateness of public policies. The democratically elected body has a broad discretion in the sphere of public policies and is politically responsible for the failure of a chosen solution. In other words, the legislation can also take non-rational steps in the domain of taxes, which is, however, not a reason for an intervention by the Constitutional Court. It will intervene only if the property rights limitation gains the intensity of the so-called "smashing effect", or if there is a violation of the principle of equality, in its accessory (in connection with other fundamental rights) or non-accessory form. 


\section{Conclusions}

Optimization of incomes and expenses, i.e. tax evasion, is undoubtedly harmful to society at large and must be tackled not only by good legislation producing perfect legal norms (i.e. simple and clear, applicable without more interpretations) but also in the field of criminal law. Although the question of the effectiveness of a tax system (i.e. the impact of taxes on individual taxpayers), is a relatively historic issue, it is not surprising that if taxes are to be used for social, political, moral or economic reasons in order to achieve a fairer distribution of national income and wealth, it is necessary to know in advance the impact of these taxes. However, it is not possible to avoid the impression that the tax burden is not optimally distributed in the Czech Republic. It has been pointed out earlier that, in relation to the overall concept of tax policy, it is not so important to whom the tax is imposed, but who carries it. Nevertheless, not all of these aspects are given due attention in terms of an overall tax and tax policy developments, although the effects of taxes on individual taxpayers have a large impact on the economy and its development. When assessing the legality of an activity from a taxpayer's point of view, it is necessary to take into account laws connected with other legislation. The taxpayer logically does not try to maximize his tax liability but on the contrary tries to use all available means to pay as little as possible while fulfilling all legal requirements. Due to the complexity of tax laws and their interaction with other rules, it is possible that taxpayers may even unintentionally commit certain illegal practices to reduce their tax liability. Proper tax assessment can be very complex so that assistance of tax advisers is often required, they should know the tax laws and be able to reduce the tax liability within the legal limitations.

\section{References}

Engliš, K.: Finanční věda (Financial Science), Brno: Polygrafie, 1929.

Kubátová, K.: Daňová teorie a politika (Tax Theory and Policy), Praha: ASPI, 2003.

Kubátová, K., Vítek., L.: Daňová politika (Tax Policy), Praha: Codex, 1997.

Kubátová, K., Vybíhal, V. et al.: Optimalizace daňového systému ČR (Optimization of the Czech Tax System), Praha: Eurolex Bohemia, 2004.

Musgrave, P.B.: Veřejné finance v teorii a praxis (Public Finances in Theory and Practice), Praha: Management Press, 1994.

Ordower, H.: Horizontal and Vertical Equity in Taxation as Constitutional Principles: Germany and the United States Contrasted. Bepress Legal Series, Working paper no. 728 (2006).

Peková, J.: Veřejné finance, úvod do problematiky (Public Finances, Introduction), Praha: ASPI, 2005. 
Pelikánová, I.: Commentary to the Civil Code, Praha: ASPI, 2017.

Radvan, M.: Zdanění majetku v Evropě (Taxation of Property in Europe), Praha: C.H. Beck, 2007.

EU: Council Directive 93/13/EEC on unfair terms in consumer contracts.

EU: European Parliament and Council Directive 2011/83/EU on consumer rights.

EU: Council Directive (EU) 2016/1164 laying down rules against tax avoidance practices that directly affect the functioning of the internal market.

CZ: Act no. 357/1992, on Inheritance tax, Gift Tax and Real Estate Transfer Tax.

CZ: Act no. 334/1992, on the Protection of Agricultural Land Fund, as amended.

CZ: Act no. 586/1992, on Income Taxes, as amended.

CZ: Act no. 185/2001, on Waste, as amended.

CZ: Act no. 170/2016, on the amendment of certain laws in the field of taxes.

CZ: Act no. 243/2016, amending certain laws in connection with the adoption of the customs act.

CZ: Act no. 254/2016, amending statutory measure of the Senate no. 340/2013 Coll., on tax on the acquisition of immovable property.

CZ: Constitutional Court: 181/2009.

CZ: Civil Code no. 89/2012, as amended.

European Commission. Taxation and Customs Union. The Missing Part, 2017. www.ec.europa.eu. www.cs.wikipedia.org. 